\title{
Determining the energy values of ingredients in pig feeds
}

\section{By D. L. Frape and MARY G. Tuck, Spillers Limited, Kennett Nutritional Centre and Pet Care Unit, Bury Road, Newmarket, Suffolk}

This subject has recently been reviewed, notably by Cole (1973), Nielsen (1970), Thorbek (1975) and Ewan (1976). Some aspects of the subject covered in those reviews will, therefore, not be referred to here and emphasis will be given to recent developments. There are two important uses of the energy value of feed ingredients. The first of these is to predict the amount of pig meat produced from a given amount of feed and the second is to achieve least-cost formulation of diets of given energy densities. The pig producer has the objective of producing a uniform quality of carcass at a feed cost commensurate with maximum profit. It is probable that the rate at which he will feed his pigs will be determined for the foreseeable future by an iterative procedure in which the intake will be increased when the rate of throughput of pigs falls below an acceptable level, or reduced when the carcass fat content exceeds an acceptable amount. Such a procedure does not require knowledge of the energy content of the feed, but does require it to be a constant. Of prime consideration, therefore, is the derivation of least-cost formulations to stated protein, limiting amino acid, energy, vitamin and mineral standards.

The cost of feed represents in the region of 0.7 of the total cost of producing pig meat on the hoof. Of the feed cost that of energy is by far the greatest component. In 1976 a fractional increase in the available energy content of a pig finisher feed was approximately six times as expensive as the same fractional increase in the lysine content. At the level of intermediary metabolism, dietary energy is apportioned between various physiological functions and a reasonable estimate would attribute more than 0.9 of the energy provided by the national pig feed directly to the functions of tissue accretion and maintenance. A reasonably reliable method is thus required to determine the energy contribution by individual ingredients to least-cost diets for these functions.

The question then which we wish to answer is how should feed ingredients be evaluated as sources of energy where the value must express the productivity of the ingredient when included in a balanced least-cost ration. Basically there are three systems by which to characterize an ingredient in these terms as a function of its heat of combustion. These are the digestible energy $\left(D_{E}\right)$, metabolizable energy $\left(Q_{E}\right)$ and net energy $\left(R_{E}\right)$ systems. The first two of these require the collection of excreta directly resulting from the consumption of known quantities of the test diet. 


\section{Digestible energy}

The apparently digested energy of feeds may be assessed from faecal output by crude chemical analysis or by calorimetry. In the first of these, feed and faeces are typically analysed for crude protein (nitrogen $\times 6 \cdot 25)(X P)$, ether extract (XL), crude fibre (XF) and nitrogen-free extractives (XX). The summation of these values each multiplied by its characteristic coefficient $k_{1} \ldots_{4}$ yields a value representing the heat of combustion of the apparently digested product of $\mathrm{I} \mathrm{kg} \mathrm{dietary} \mathrm{dry} \mathrm{matter}$ (DM). Although the random errors associated with this procedure would appear to loom no larger than those found in digestible energy measurements (Thorbek, 1975), Nielsen (1970) has shown that the starch content of XX decreases as fibre increases. As a consequence of the cost of biological determinations and because of the inherent variability between samples of the same ingredient, a number of equations have been derived to predict digestible and metabolizable energies from easily determined chemical characteristics of diets. The following are examples:

$$
\begin{aligned}
& \mathrm{E}_{\mathrm{D}} \%=9 \mathrm{I} \cdot 48-2 \cdot 22 \mathrm{XF} \% \pm 2 \cdot 2 \mathrm{I} \text { (Fowler, 1975) } \\
& \mathrm{E}_{\mathrm{D}}=0.00492 \mathrm{E}_{\mathrm{I}}-4 \cdot 54-0.168 \mathrm{NDF} \% \pm 0.448 \text { (King \& Taverner, 1975) } \\
& \mathrm{E}_{\mathrm{D}}=0.460 \mathrm{XP} \%+0.625 \text { (acidXL\%) +0.377XX\%-21.05; } \mathrm{R}=0.95 \text { (Morgan, } \\
& \text { Cole \& Lewis, 1975 } b \text { ) } \\
& \mathrm{E}_{\mathrm{Q}}=0.416 \mathrm{XP} \%+0.605 \text { (acidXL\%)+0.367XX\%-20.06; } \mathrm{R}=0.94 \text { (Morgan, } \\
& \text { Cole \& Lewis, } 1975^{b} \text { ) }
\end{aligned}
$$

where $E_{1}, E_{D}$ and $E_{Q}$ are gross, digestible and metabolizable energies (MJ/kg DM); $\mathrm{XF}, \mathrm{NDF}, \mathrm{XP}, \mathrm{XL}$ and $\mathrm{XX}$ are crude fibre, neutral detergent fibre, crude protein, ether extract, nitrogen-free extractives in DM respectively.

The second method of $E_{D}$ assessment has now largely supplanted crude chemical estimations on faeces following the development of adiabatic calorimeters with thermistors in which the heats of combustion of food and faeces are measured giving a direct, and therefore more reliable, estimate.

The procedure in our laboratory is to collect all excreta during the last $6 \mathrm{~d}$ of a Io $d$ period. Each of fourteen pigs, divided into two groups of seven, is subjected to four such consecutive periods in a trial with typically three or four ingredients evaluated at the same time in seven diets. Each pig receives a different diet in each period in such a way that each of the two groups of pigs forms a balanced incomplrte latin square (Youden Square) design. The standard errors of mean $E_{D}$ values for individual ingredients, are approximately 0.01 of the mean for cereals and protein concentrates, but more for fats and other ingredients tested at low concentrations. A basal premix containing fishmeal, L-lysine, DL-methionine, minerals and vitamins, comprises 0.0325 of each diet. Frederiksen (1973) has considered the effects on energy values derived for ingredients caused by their inclusion at low concentrations in the test diet and by incorrect values being assumed for the energy contribution of the basal premix. Systematic errors resulting from incomplete food consumption and incomplete excreta collection under our conditions are probably of minor importance as the losses would appear 
to be small. Urine is collected in conc. $\mathrm{H}_{2} \mathrm{SO}_{4}$ and all faeces are frozen daily. All the faeces are thawed and weighed before mixing in a Hobart when $4 \cdot 0^{-3}$ of the weight is lost. If this is a loss of moisture it represents a source of systematic bias which would be in the opposite direction to that resulting from incomplete food consumption and excreta collection. The faeces are then dried when losses of dry matter and of nitrogen can be as high as 0.2 of the total in ruminant faeces (Falvey \& Woolley, 1974). The complete collection of faeces may be avoided by the addition of a dye marker to test diets. Digestibilities are then calculated from the relative concentrations of dye in feed and in faeces. Although this overcomes the errors associated with incomplete food consumption, incomplete faecal collection and moisture loss from faeces, it is subject to sampling variation and is of no advantage in overcoming the bias resulting from $\mathrm{N}$ or energy losses during drying.

We have studied the day to day variation in faecal $\mathbf{N}$ and $\mathbf{P}$ output in growing pigs given two feeds/day at the rates of $37 \mathrm{~W}^{0.7}, 3 \mathrm{IW}^{0.7}$ and $25 \mathrm{~W}^{0.7} \mathrm{~g} / \mathrm{feed}$. No trends or systematic oscillations could be detected and there was only slight evidence that $\mathrm{N}$ output on successive days might be serially correlated (negatively). The effect of length of faecal collection period on precision for two theoretical models is shown in Fig. 1 . In both cases, the choice of $6 \mathrm{~d}$ for the length of collection period seems reasonable. There were no trends or patterns of decreasing variation in faecal $\mathbf{N}$ or $\mathbf{P}$ and so no evidence that a longer period than four days is necessary for adaptation to a diet. This evidence concurs with that presented by Thorbek (1975). Variation in faecal $\mathrm{N}$ output from day to day was similar for both

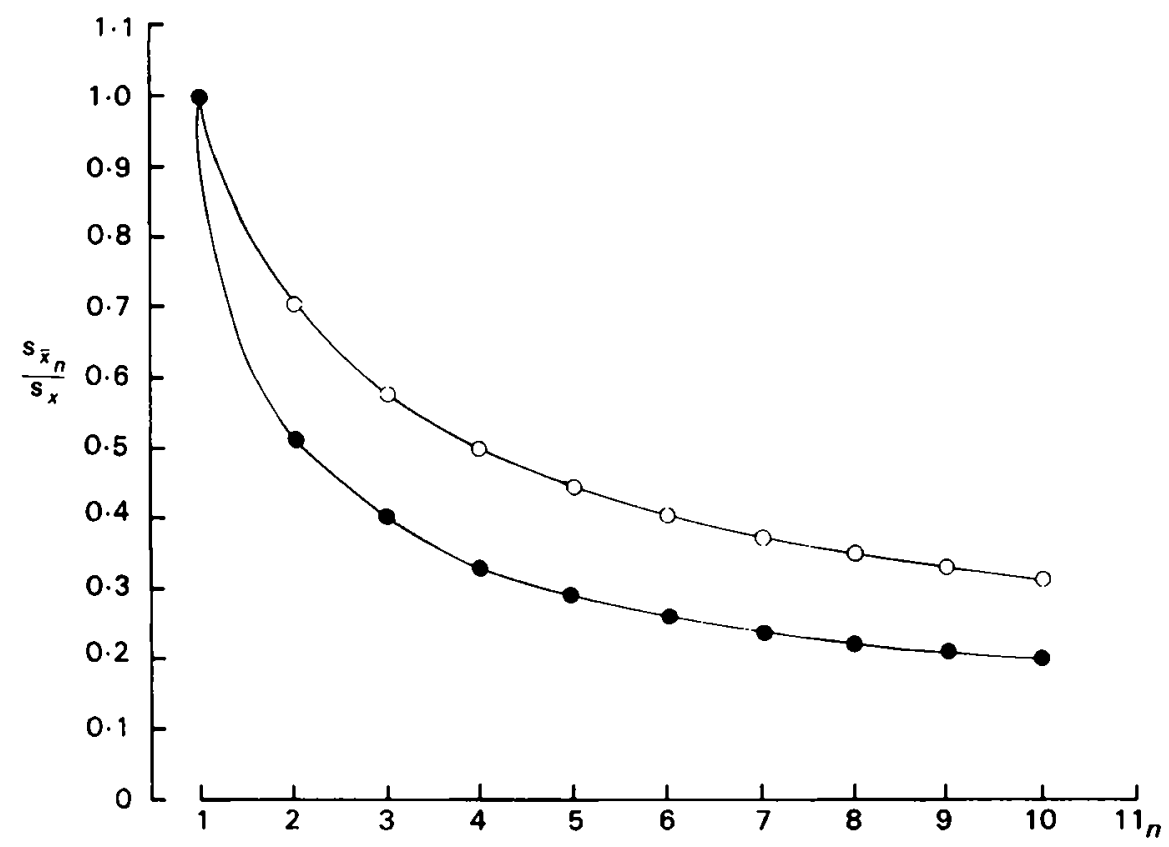

Fig. 1. Relationship of length of collection period in days $(x)$ to variation in $\bar{x}_{n}$ for uncorrelated observations $(O)$ and also for successively correlated observations following a first order autoregressive scheme with $\rho=-0.5(0)$. 
low and high fibre diets so that proportionately the variation was greater for the low fibre than for the high fibre diet. We have not investigated variation over short time intervals, but diurnal variation in urinary $\mathrm{N}$ excretion rate which results from feeding pigs twice/day can apparently be avoided by ad lib. feeding (Furuya, Takahashi \& Kameoka, 1971).

Satisfactory measurements derived from pigs restrained in crates also relies upon the absence of stress. Ostrovski (1974) reported that short term stress reduced protein and organic matter digestibility by amounts which increased as the frequency of stress increased. In our crates the risks of abrasions and other trauma are slight when pigs are held for several months.

\section{Metabolizable energy}

The $E_{D}$ of food is by no means all recoverable in useful animal products. Some workers, therefore, advocate the determination of metabolizable energy, i.e. that which is available to the tissues for productive use. In the pig methane losses are small-for normal diets about 0.01 of the $\mathrm{E}_{\mathrm{D}}$ (Bowland, Bickel, Pfirter, Wenk \& Schurch, 1970) - and therefore in practice the $E_{Q}$ is simply assumed to be that portion of the digestible energy not lost in the urine. A proportion of the $\mathrm{N}$ from deaminated amino acids is excreted in the urine as urea. Although this has a heat of combustion of $22.8 \mathrm{MJ} / \mathrm{kg} \mathrm{N}$ not all urinary $\mathrm{N}$ occurs in this form, and at normal levels of dietary protein the heat of combustion of pig urine is approximately $38.4 \mathrm{MJ} / \mathrm{kg} \mathrm{N}$ (Morgan, Cole \& Lewis, 1975a). When dietary crude protein is increased to $400 \mathrm{~g} / \mathrm{kg}$ (DM basis) the heat of combustion falls to approximately $30 \mathrm{MJ} / \mathrm{kg} \mathrm{N}$. Urinary $\mathrm{N}$ losses increase as dietary protein is raised so that high protein ingredients are likely to incur a greater handicap than cereals in the computation of their metabolizability. Thus $\mathrm{E}_{\mathrm{Q}}$ is affected by dietary protein level and by the way it is utilized and so is not a constant characteristic of an ingredient.

$\mathrm{E}_{\mathbf{Q}}$ may be calculated from the proximate composition of digestible dietary components or as a proportion of $\mathrm{E}_{\mathrm{D}}$ : approximately $0.98 \mathrm{E}_{\mathrm{D}}$ for cereals and 0.95 $\mathrm{E}_{\mathrm{D}}$ for protein concentrates. Morgan et al. (1975a) allow for variation in protein intake:

$$
\begin{array}{ll}
E_{Q}=E_{D}\left(0.997-1 \cdot 89 \times 10^{-4} X P_{I}\right) & R^{2}=0.88 \\
s_{b}=0.15 \times 10^{-4} &
\end{array}
$$

where $\mathrm{XP}_{\mathbf{I}}$ is crude protein $(\mathrm{g} / \mathrm{kg}$ dietary $\mathrm{DM})$.

As the objective is to predict the value of an ingredient when it forms a constituent of a balanced diet, several investigators have adopted the practice of calculating $E_{Q}$ either at $N$ equilibrium $\left(E_{Q} N_{0}\right)$ or when a fixed proportion of dietary $\mathbf{N}$ is retained. The retention under many practical situations is approximately 0.3 of intake and Morgan et al. (1975a) calculated $\mathrm{E}_{\mathrm{Q}}$ at this level. However, neither of these adjustments takes account of the actual metabolizability and both suffer from the disadvantage that $E_{Q}$ is affected by the $N$ 
content of the diet. One would not anticipate much variation in urinary $\mathrm{N}$ amongst least-cost diets all formulated to the same constraints so that, in this case, a calculation of $E_{Q}$ based upon an estimate of urinary $N$ in reality provides no additional information to that provided by $\mathrm{E}_{\mathfrak{D}}$.

\section{Net energy}

As the function of a feed evaluation system is the prediction, with reasonable confidence, of the amounts of protein and fat deposited for a given protein and energy intake, an evaluation system must lead to the prediction of the net energy $\left(E_{R}\right)$ content of a diet.

Three methods of indirect calorimetry are most commonly used to calculate heat production and energy gain: carbon-nitrogen $(\mathrm{CN})$, respiratory quotient $(\mathrm{RQ})$ and carcass analysis. The errors appear to be lower when the slaughter method is adopted. The proportional gain in energy calculated from RQ determinations was 0.02 (Thorbek, 1975) and 0.05 (Nielsen, 1970) lower than that calculated by the $\mathrm{CN}$ method. Nielsen's results tend to indicate that $R Q$ and $\mathrm{CN}$ balance methods over-estimate energy retention and that the slaughter method systematically under-estimates it, whereas Fuller \& Boyne (1972) concluded that $R_{E}$ calculated by respiratory exchange and comparative slaughter methods were in close agreement. Heat production determined from $\mathrm{RQ}$ and $\mathrm{CN}$ observations requires general assumptions about the compositions of tissues and of fuels oxidized. Thorbek's RQ results indicate greater than expected heat production arising from the consumption of maize, when the cereal fat was assumed to have a heat of combustion equal to that of palmitic acid.

The $Q_{E}$ expenditures incurred in depositing I kg protein and I $\mathrm{kg}$ fat have been estimated by several workers to fall between 37 and $5^{\mathrm{I}} \mathrm{MJ}$ and between 48 and $5^{8}$ MJ, respectively. The partial efficiencies of $\mathrm{E}_{\mathbf{Q}}$ utilization for protein synthesis $\left(k_{\mathrm{n}}\right)$ and fat synthesis $\left(k_{f}\right)$, therefore, fall in the ranges of 0.43 to 0.63 and 0.69 to $0.8 \mathrm{I}$ respectively. The difference between $k_{\mathrm{n}}$ and $k_{\mathrm{f}}$ partially explains the higher mean efficiency of the heavier pig growing at normal rates. The extent of the two ranges represents random errors, variation in age and rate of protein deposition of pigs, and variation in the quality of both dietary protein and substrates for fat formation. Variation in the efficiency by which the $\mathrm{E}_{\mathrm{Q}}$ of various pure substrates derived from feeds is utilized in fat synthesis has been determined by workers at Rostock and elsewhere. The following are average values for $k_{\mathrm{f}}: \operatorname{starch} 0.76$; vegetable oil 0.86 ; fish protein 0.66 ; mixed proteins 0.62 ; acetate 0.47 .

There is an increase in $k_{w}$ with increasing dietary $E_{Q}$ and $q$ (Nielsen, 1970), as found in ruminants (Blaxter, 1974). Just, Rasmussen \& Hansen (1976) consider that this effect is attributable to one or more of the following factors: changing chemical composition of XX, a relation between feed DM and the energy required for digestive processes, systematic errors, and differing metabolic efficiencies of the nutrients absorbed as indicated in the above $k_{\mathrm{f}}$ values. The effect of dietary energy concentration was formalized by Nielsen (1970):

$$
\mathrm{E}_{\mathrm{R}}=0 \cdot 78 \mathrm{E}_{\mathrm{Q}}-1 \cdot 958 \pm 0 \cdot 2 \mathrm{13}
$$


although the correlation between $E_{Q}$ and $E_{R}$ was only 0.46 . The concentration of energy is partly an expression of the content of dietary ether extract and crude fibre:

$$
\begin{aligned}
& R_{E}=0.53 Q_{E}+0.0092 I_{X L}-0.0067 I_{X F}-3.76 \quad \text { (Nielsen, I970), } \\
& \begin{array}{llll}
s_{\mathrm{b}} & 0.08 & 0.0052 & 0.0017
\end{array}
\end{aligned}
$$

but the dependence of $R_{E}$ on dietary fat is obviously uncertain. The effect of crude fibre is considered by Nielsen to be an index of an associated change in the composition of XX. Just $e t$ al. (1976) also reported that $k_{\mathrm{w}}$ decreased by 0.004 for an increase of 0.01 in the proportion of dietary crude fibre and increased by 0.003 for an increase of $0.0 \mathrm{r}$ in the proportion of dietary lipids.

From intensive investigations by Schiemann, Nehring, Hoffman, Jentsch \& Chudy (1971) at Rostock, multiple regression equations relating crude dietary constituents to digestible, metabolizable and net energies, have been derived:

$$
\begin{aligned}
& D_{E}=22 \cdot 5 X_{1}+37 \cdot 3 X_{2}+17 \cdot 4 X_{3}+17 \cdot 5 X_{4} \pm 180 \\
& Q_{E}=18 \cdot 8 X_{1}+36 \cdot 1 X_{2}+16 \cdot 7 X_{3}+17 \cdot 4 X_{4} \pm 243 \\
& R_{E}=10 \cdot 0 X_{1}+32 \cdot 3 X_{2}+0 \cdot 04 X_{3}+13 \cdot 7 X_{4} \pm 531
\end{aligned}
$$

where $X_{1} \ldots{ }_{4}$ are dietary, crude protein $(\mathrm{kg} / \mathrm{d})$, fat $(\mathrm{kg} / \mathrm{d})$, crude fibre $(\mathrm{kg} / \mathrm{d})$ and nitrogen-free extractives $(\mathrm{kg} / \mathrm{d})$ respectively. Although the first two equations are similar, the third differs from them notably in the $X_{3}$ coefficient, and so it is unlikely that $R_{E}$ can be predicted accurately from $Q_{E}$ alone. In addition, the third equation is probably unreliable as the $\mathrm{X}_{4}$ coefficient is likely to alter with a change in $\mathrm{X}_{3}$ (Just et al. 1976).

Similar relationships were found by us amongst specific energies in the young pig for twelve ingredients using data published by Ewan (1976). The correlation coefficients are given below:

$\begin{array}{lclll}E_{I} & I & & & \\ E_{D} & 0.45 & I & & \\ E_{Q} & 0.43 & I \cdot 00 & I & \\ E_{R} & -0.19 & 0.60 & 0.62 & I \\ & E_{I} & E_{D} & E_{Q} & E_{R}\end{array}$

It is evident that whereas $\mathrm{E}_{\mathrm{Q}}$ and $\mathrm{E}_{\mathrm{D}}$ are measures of a similar characteristic, $\mathrm{E}_{R}$ is quite distinct from them and from the gross energy. As the objective of energy evaluation is the prediction of net energy it is apparent that the other measures are poor direct predictors of it.

The use of a constant $E_{R}$ value for an ingredient in a pig diet assumes addivity and that for the major products of digestion the efficiencies of utilization of $E_{Q}$ are proportionately the same whatever the rate of growth.

Voluntary food intake rises almost linearly with $W$ whereas $Q_{E}$ required for maintenance is a linear function of a fractional power of $\mathrm{W}$, and so the proportion 
of feed energy used productively can increase as the pig grows. Thorbek (1975) reported that out of $10.9 \mathrm{MJ} \mathrm{Q}_{\mathrm{E}}$ consumed/d by young castrates the proportion 0.16 was recoverable in energy gain, whereas from $36 \mathrm{MJ} \mathrm{Q}_{E} / d$ the proportion 0.5 was recoverable at $80 \mathrm{~kg}$ live weight. The younger animals were relatively more active and little fat was accumulated, but at $80 \mathrm{~kg}$ live weight $380 \mathrm{~g} \mathrm{fat} / \mathrm{d}$ was deposited. Daily $\mathbf{N}$ deposition from adequate diets does not differ much between 35 and $80 \mathrm{~kg}$ live weight and Thorbek (1975) derived the following prediction equation from her results:

$$
\mathrm{N} \max (\mathrm{g} / \mathrm{d})=\mathrm{r} \cdot 47 \mathrm{~W}^{0.75}-0.0266 \mathrm{~W}^{\mathrm{r} \cdot 50}
$$

Thorbek (1975) and Ewan (1976) considered it unlikely that pigs up to $25 \mathrm{~kg}$ live weight could achieve a maximum rate of $\mathrm{N}$ deposition because limitations of capacity preclude an adequate intake of energy unless a grain-based diet is supplemented with fat (Phillips \& Ewan, 1977). Over that weight pigs receiving a diet adequate in protein can achieve a maximum rate and normal variations in energy density of the diet merely alter the rate of fat deposition, particularly if the rate of feeding exceeds $2 \times$ maintenance (Close \& Mount, 1976). Growing at normal rates, pigs weighing 10 to $15 \mathrm{~kg}$ deposit very little fat whereas at $100 \mathrm{~kg}$ a small proportion of the dietary energy is directed towards protein accretion. Under Danish conditions (Nielsen, 1970) of restricted feeding for bacon production, the partition of $Q_{\mathrm{E}}$ in $50 \mathrm{~kg}$ pigs was:

$$
\begin{gathered}
25.72 \\
Q_{\mathrm{E}}
\end{gathered}=\underset{\text { Maintenance }}{7.99}+\underset{\substack{\text { Protein } \\
\text { accretion }}}{6.88}+\underset{\text { accretion }}{\text { Fat }}
$$

Two facts emerge at normal rates of feeding: firstly, that maintenance absorbs a decreasing proportion of $\mathrm{Q}_{\mathrm{E}}$ as body-weight increases and secondly, the ratio, fat gained/d: protein gained/d, increases as the pig grows.

We may now ask whether $k_{\mathrm{m}}$ differs materially from $k_{\mathrm{w}}$. In ruminants the spread in $k_{\mathrm{f}}$ values for various nutrients is greater than the spread in $k_{\mathrm{m}}$ for those same nutrients. It is likely that this is also true in pigs, but here the energy of VFA represents only a minor proportion of $Q_{E}$ and so one would expect the difference between a least-cost energy formulation at energy equilibrium and at three times this to be smaller. De Goey \& Ewan (1975a) found similar values for $k_{\mathrm{m}}$ and $k_{\mathrm{w}}$ in young pigs, and Nielsen (1970) concluded from an analysis of two sets of data that when concentrate diets within the normal range were given, the effect of energy concentration on $k_{\mathrm{f}}$ in adult pigs was similar to that on $k_{w+m}$ in growing pigs:

$$
\begin{aligned}
& E_{R f}=0 \cdot 77 E_{Q}-1 \cdot 042 \pm 0 \cdot 402 ; n=39 \quad \text { (Schiemann et al. 1971) } \\
& \left.E_{R(w+m)}=0.75 E_{Q}-1 \cdot 013 \pm 0 \cdot 255 ; n=40 \quad \text { (Nielsen, } 1970\right) .
\end{aligned}
$$

The use of $E_{R}$ values in least-cost ration formulation does not require that ingredient $k$ values are the same for the three functions, fat deposition, protein 
deposition and maintenance, but changes in $k$ must be proportionately the same for each ingredient. The above evidence gives some assurance of this.

In ruminants $q$ declines for high fibre diets (proportion of $X F$ in diet $>0.16$ ) at high rates of food intake and $R_{E}$ declines as a function of $I_{E}$ as intake rises towards twice maintenance (Blaxter, 1974). In young pigs the rate of feeding within reasonable limits has no effect (Fuller \& Boyne, 1972; Burlacu, Illiescu \& Stravi, 1976). We have not found $E_{D}$ to change significantly with feeding level and $\mathrm{De}$ Goey \& Ewan ( $1975 a$ ) found no relationship between the level (in the proportions 0.02 and 0.05 of body-weight) and $E_{D}, E_{Q}$ or $E_{R}$ in young pigs.

It is assumed in least-cost ration formulation that the energy contributions of individual ingredients in a feed are additive, and therefore, that the energy contributed per unit remains constant whatever the other constituents of the diet may be (Frape, Tuck \& Boxall, 1976). Kromann et al. (1976) found some evidence, in each of the measures $E_{D}, E_{Q}$ and $E_{R}$ in pigs, of interactions between ingredients. Pig digestibility trials conducted in our laboratory have indicated small, but significant departures from linearity of substitution although ingredient proportions beyond normal limits were used. In four recent experiments such departures have accounted for proportions between 0.03 and 0.13 of the diet sum of squares. Thus the assumption may not be entirely valid and is certainly not so in ruminants. Clearly the complications associated with the use of net energy, either measured or predicted, in a least-cost ration formulation system for growing pigs would be less formidable than those which confront the formulator of cattle feeds (Kromann, 1973).

The $\mathrm{E}_{\mathbf{D}}$ determination of individual ingredients is relatively quick and the efficiency with which it is utilized in pigs given balanced diets depends to some extent upon dietary energy concentration and would appear to apply to genetically disparate groups of pigs (Fuller, Webster, MacPherson \& Smith, 1976). Ingredient $E_{D}$ values suitably adjusted for some measure of dietary fat and fibre might form the basis of a system for predicting $E_{R}$ of mixed diets for growing pigs. The development of more definitive procedures for the chemical determination of lipids and fibre would facilitate greater precision of the proposed system. This procedure could also accommodate adjustments in values for various samples of the same ingredient, and the over-valuing of fibrous feeds which occurs when the $E_{D}$ system is used would be avoided.

\section{Appendix: Index of symbols}

$\mathrm{XP}, \mathrm{XL}, \mathrm{XF}, \mathrm{XX}$ : Weende proximate organic principles of feeds: crude protein, ether extract, crude fibre and $\mathrm{N}$-free extractives $(\mathrm{kg})$, respectively.

$I_{E}, F_{E}, D_{E}, Q_{E}, R_{E}$ : rates per day of energy: intake, excreted in faeces, apparently digested, metabolized and deposited or dissipated as heat (MJ/d).

$E_{D}, E, E_{R}$ : energy: apparently digested, metabolized and deposited or dissipated as heat $(\mathrm{MJ} / \mathrm{kg}$ feed $\mathrm{DM})$. 
d: apparent digestibility of feed.

$\mathrm{q}$ : apparent metabolizability of feed.

$\mathrm{k}: \Delta \mathrm{R}_{E} / \Delta \mathrm{Q}_{\mathrm{E}}$

\section{Subscripts}

m: maintenance.

w: growth.

f: depositing fat.

$\mathrm{n}$ : depositing protein.

\section{REFERENCES}

Blaxter, K. L. (1974). Nutrition Conference for Feed Manufacturers Vol. 7, p. 3 [H. Swan \& D. Lewis, editors]. London: Butterworths.

Bowland, J. P., Bickel, H., Pfirter, H. P., Wenk, C. P. \& Schurch, A. (1970). Y. Anim. Sci. 31, 495.

Burlacu, G., Illiescu, M. \& Starvi, J. (1976). Proc. 7th Symp: 181. Vichy, France [M. Vermorel, editor]. Clermont-Ferrand: G. de Bussac (EAAP Publ. no. 19).

Close, W. H. \& Mount, L. E. (1976). Proc. 7th Symp: 173, Vichy, France [M. Vermorel, editor]. Clermont-Ferrand: G. de Bussac (EAAP Publ. no. 19).

Cole, D. J. A. (1973). Nutrition Conference for Feed Manufacturers Vol. 7, p. 81 [H. Swan \& D. Lewis, editors]. London: Butterworths.

De Goey, L. W. \& Ewan, R. C. (1975a). F. Anim. Sci. 40, 1045.

De Goey, L. W. \& Ewan, R. C. (1975b). J. Anim. Sci. 40, 1052.

Ewan, R. C. (1976). Distillers Feed Research Council 31, 16.

Falvey, L. \& Woolley, A. (1974). Aust. f. exp. agric. Anim. Husb. 14, 716.

Fowler, V. R. (1975). Proc. Br. Soc. Anim. Prod. 4, 11.

Frape, D. L., Tuck, M. G. \& Boxall, R. C. (1976). f. agric. Sci., Camb. 86, 325.

Frederiksen, J. H. (1973). Acta Agric. scand. 23, 17.

Fuller, M. F. \& Boyne, A. W. (1972). Br. F. Nutr. 28, 373.

Fuller, M. F., Webster, A. J. F., MacPherson, R. M. \& Smith, J. S. (1976). Proc. 7th Symp: 177. Vichy, France [M. Vermorel, editor]. Clermont-Ferrand: G. de Bussac (EAAP Publ. no. 19).

Furuya, S., Takahashi, S. \& Kameoka, K. (1971). f. Nutr. 101, 1373.

Just, A., Rasmussen, O. K. \& Hansen, H. L. (1976). Proc. 7th Symp: 289. Vichy, France [M. Vermorel, editor]. Clermont-Ferrand: G. de Bussac (EAAP Publ. no. 19).

King, R. H. \& Taverner, M. R. (1975). Anim. Prod. 21, 275.

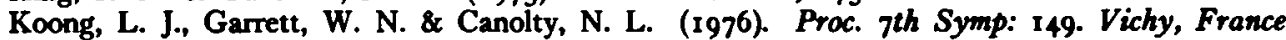
[M. Vermorel, editor]. Clermont-Ferrand: G. de Bussac (EAAP Publ. no. 19).

Kromann, R. P. (1973). J. Anim. Sci. 37, 200.

Kromann, R. P., Froseth, J. A. \& Meiser, W. E. (1976). F. Anim. Sci. 42, $145^{1}$.

Morgan, D. J., Cole, D. J. A. \& Lewis, D. (1975a). J. agric. Sci., Camb. 84, 7.

Morgan, D. J., Cole, D. J. A. \& Lewis, D. (1975b). Y. agric. Sci., Camb. 84, 19.

Nehring, K., Beyer, M. \& Hoffmann, B. (editors). (1970). Futtermitteltabellenwerk. Berlin: VEB Deutscher, Landwirtschaftsverlag.

Nielsen, A. J. (1970). $38 \mathrm{I}$ Beretning fra forsøgslaboratoriet $460 \mathrm{pp}$. København: I kommission hos Landhusholdningsselskabets, Forlag.

Ostrowski, H. T. (1974). N.Z. F. agric. Res. 17, 305.

Phillips, B. C. \& Ewan, R. C. (1977). J. Anim. Sci. (In the Press).

Schiemann, R., Nehring, K., Hoffmann, L., Jentsch, W. \& Chudy, A. (197I). Energetische futterbewertung und Energienormen. Berlin: VEB Deutscher, Landwirtschaftsverlag.

Thorbek, G. (1975). 424 Beretning fra Statens, Husdyrbrugs forsog I kommission hos Landhusholdningsselskabets, Forlag, København. 